\title{
Entre París y Oviedo: 15 cartas inéditas de Enrique Gómez Carrillo a Leopoldo Alas, Clarín
}

\author{
Jesús RUBIO JimÉNEZ y Antonio DEAÑO GAMALLO \\ Universidad de Zaragoza
}

\begin{abstract}
RESUMEN
El objetivo central de este artículo es dar a conocer 15 cartas enviadas por Enrique Gómez Carrillo a Leopoldo Alas. Hasta ahora inéditas, se hallaban en el Archivo de Dionisio Gamallo Fierros. La publicación de las mismas reafirma la buena relación que tuvieron el escritor español y el guatemalteco, así como los intereses comunes.

Palabras clave: Clarín, Enrique Gómez Carrillo, epistolario.

Between Paris and Oviedo: 15 unpublished letters of Enrique Gómez Carrillo to Leopoldo Alas, Clarín
\end{abstract}

\begin{abstract}
The central aim of this article is to announce 15 letters sent by Enrique Gómez Carrillo to Leopoldo Alas. Till now unpublished, they were situated in Dionysus Gamallo Fierros's File. The publication of the same ones reaffirms the good relation that the Spanish writer and the Guatemalan had, as well as the common interests.
\end{abstract}

Key words: Clarín, Enrique Gómez Carrillo, Letters.

Las relaciones entre el escritor y crítico guatemalteco Enrique Gómez Carrillo (1873-1927) y Leopoldo Alas, Clarín (1852-1901) han sido descritas en diferentes ocasiones. ${ }^{1}$ Hasta donde sabemos, simpatizaron pronto, Clarín le dedicó una atención crítica inusitada al todavía joven escritor, cruzaron un buen número de cartas y después incluso prologó su libro Almas y cerebros (1898). Por su lado,

1 Allen Phillips, «Nueva luz sobre Clarín y Gómez Carrillo», Revista de Archivos, Bibliotecas y Museos, LXXXI, 1978, pp. 757-779. John Kronik, «Enrique Gómez Carrillo, Francophile Propagandist», Symposium, 21, 1969, pp. 50-60. Y «Enrique Gómez Carrillo a la defensa de Clarín», Revista de Literatura, LXV, 129, 2003, pp. 239-256. Más general, Anna Ashhurt, La literatura hispanoamericana en la crítica española, Madrid, Gredos, 1980. 
Gómez Carrillo se aplicó a difundir internacionalmente la obra de Clarín, reconociendo desde el comienzo sus orientaciones y agradeciéndole sus elogios, aunque estos fueron discretos. Algo debió ver Clarín en aquel joven que llamó su atención y se dispuso a ejercer su magisterio con él como hizo con Rafael Altamira o Salvador Rueda. Después se fueron añadiendo circunstancias e intereses mutuos que reforzaron esta sintonía inicial.

Con todo, el Epistolario conocido de Clarín tan solo recoge una de las cartas que le escribió, mientras que las que el guatemalteco dirigió a Clarín han estado fuera del alcance de los estudiosos. ${ }^{2}$ En el Archivo de Dionisio Gamallo Fierros se localizan 15 de estas cartas — dos de ellas incompletas-, cuya publicación constituye el objetivo central de este estudio. ${ }^{3}$

Hasta no hace mucho se ha considerado que se pusieron en contacto cuando Gómez Carrillo vino a Madrid en 1892, pero lo cierto es que en 1890 ya le envió al menos dos cartas a Clarín, la primera de ellas el 30 de enero [1]. ${ }^{4}$ No mucho después, el joven periodista dedicó dos artículos a comentar el folleto Rafael Calvo y el teatro español en El Imparcial de Guatemala: «El último folleto de Clarín». ${ }^{5}$ Tanto la carta como los artículos denotan la admiración con que seguía la obra crítica de Clarín. Llegaba a decirle que

he estado durante algunos años leyendo todo lo que usted escribe en el Madrid Cómico y aprendiéndome de memoria pedazos de sus libros y de sus folletos

${ }^{2}$ Gómez Carrillo la incorporó a sus memorias: Treinta años de mi vida. La miseria de Madrid, libro tercero y último, Madrid-Buenos Aires, Editorial de la Sociedad Española de Librería, 1921. El capítulo «Una carta de Clarín». Más adelante citamos una segunda carta que se conserva en el Archivo de la familia Tolivar Alas, que ha sido editada parcialmente por Yvan Lissorgues, Leopoldo Alas, Clarín, en sus palabras (1852-1901), Oviedo Ediciones Nobel, 2007, p. 564.

${ }^{3}$ Archivo de Dionisio Gamallo Fierros. Ribadeo (Lugo). Parte de las cartas carecen de fechas o se conservan incompletas. Hemos procurado completar sus datos cronológicos para su ordenación en nuestra edición.

${ }^{4}$ En nuestra presentación se indica en adelante entre corchetes al número de la carta a la que remitimos tal como quedan ordenadas en esta edición.

${ }^{5}$ Enrique Gómez Carrillo, «El último folleto de Clarín, I» y «El último folleto de Clarín, II», El Imparcial (Guatemala), 24-II-1890 y 27-II-1890. Pueden verse reproducidos y comentados en J. Kronik, art. cit. de 2003.

También buscaba abrirse camino animosamente en la prensa española y de hecho, Juan Manuel González Martel ha localizado dos artículos suyos en Las Dominicales del Libre Pensamiento los días 11 y 18 de octubre de 1890 («Gómez Carrillo y su primera colaboración en la prensa europea», Magazine modernista, 19-V-2009. Edición digital): ambas colaboraciones trataban sobre la situación de Centro América. Cuando comenzó a colaborar con más continuidad lo hizo con «Sensaciones de estética. Sobre el arte de la crítica», El Imparcial (Madrid), 23-II-1892. 
literarios; citándolo como verdadera autoridad en todo lo que escribe, y, en fin, pensando en usted todos los días y a todas horas y hasta con deseos (no se ría usted, o, si quiere, ríase, pero créame por mi palabra y por mis barbas) con deseos, digo, de hacer un segundo viaje a España sólo por conocerle. [1]

Y hasta había concebido el proyecto de escribir un folleto sobre Clarín, siguiendo el modelo de los suyos. No sabemos si Clarín respondió a la petición de datos personales que le hacía y si Gómez Carrillo finalmente escribió el folleto que se proponía, pero lo cierto es que Clarín conservó su carta y una segunda fechada en febrero, citada parcialmente por Yvan Lissorgues. En esta, le daba cuenta de que la librería de A. Casa había recibido «cuarenta ejemplares de Rafael Calvo y antes de cuatro horas se vendieron todos y aun se habrían vendido más si los hubiera». ${ }^{6} \mathrm{Le}$ pedía que le enviara un ejemplar de su biografía de Galdós, ya que había perdido el que había comprado, y hasta le enviaba a Clarín algunos recortes de prensa donde Francisco Gavidia en el periódico El País le atacaba. Siempre dispuesto a la polémica, Clarín respondió a estos ataques irónicamente en Madrid Cómico el 5 de abril de 1890, reiterando una posición muy suya: la independencia de sus juicios, sus críticas a los modernistas — personificados en Rubén Darío a quien acusaba de poeta ripioso- - y la defensa de que debían formar todos un pueblo: «Seamos, señor Gavidia, un pueblo solo en dos continentes. Pero concédaseme la extradición de los ripios, cobíjelos una u otra bandera.» ${ }^{7}$

Cuando Gómez Carrillo, viviendo en España y después de residir en París unos meses, publicó su primer libro Esquisses (Siluetas de escritores y artistas), se lo remitió y Alas le dedicó parte de uno de sus paliques en Madrid Cómico el 20 de febrero de $1892 .{ }^{8}$ El comentario de Clarín fue moderado, pero al joven debió parecerle extraordinario el hecho mismo de que el gran crítico a quien tanto admiraba se ocupara de su librito. En una carta queda testimonio del interés con que esperaba sus palabras [4]. A Clarín no le gustó el título por francés y afectado concediendo demasiada importancia a su estancia parisiense, pero encontraba en él algunos rasgos que le interesaron:

Personalmente, el señor Gómez no es arrogante, ni desdeñoso, ni se muestra orgulloso.

${ }^{6}$ Yvan Lissorgues, Leopoldo Alas, Clarín, en sus palabras, ob. cit., p. 564.

${ }^{7}$ Clarín, «Palique», Madrid Cómico, 5-IV-1890.

${ }^{8}$ Enrique Gómez Carrillo, Esquisses (Siluetas de escritores y artistas): Oscar Wilde, Armand Silvestre, Charles Maurras, Paul Verlaine, etc., Madrid, Imprenta de la Viuda de Hernando, 1892. Se han realizado diferentes ediciones posteriores; véase la preparada por Ricardo de la Fuente Ballesteros, Esquisses (Siluetas de escritores y artistas), San Luis de Potosí, 2009. 
Su libro es curioso, aun para quien tenga costumbre de seguir paso a paso el movimiento literario francés: está en algunos pasajes escrito con elocuencia, y se recomiendan particularmente las páginas dedicadas a describir al célebre Paul Verlaine en su vida de hospital, donde le tiene más su miseria que sus enfermedades. ${ }^{9}$

Advertía finalmente del peligro que suponía la identificación con estos modelos para los escritores jóvenes más fogosos que prudentes y con poca experiencia, para concluir: «Si nuestros poetillas descriptivos y becquerianos se hacen simbolistas, místicos, etcétera, no hay quien pare aquí, hablando con respeto.»

Aún así, a Gómez Carrillo le supo a gloria la atención prestada por Clarín a su librito de semblanzas de escritores raros en su mayoría y a parte de los cuales había frecuentado en París: Verlaine, Wilde, Silvestre, Maurras y también hispánicos: Darío, Alejandro Sawa. Comenzaba a tejerse una amistad que no haría sino crecer en los años siguientes.

Profundamente agradecido por el espaldarazo que suponía para él la crítica del maestro - una verdadera «dedada de miel», según lo calificaría más tarde Salvador Rueda-, Gómez Carrillo se puso a su completa disposición como testimonian las siguientes cartas y mostró un gran empeño, una vez instalado en París, en difundir su obra en Hispanoamérica y traducida al francés. Si alguna reticencia pudo haber al comienzo, estos gestos la disiparon por completo. Nunca olvidó esta reseña y todavía en sus memorias le dedicaba un capítulo, titulándolo «El primer triunfo de mi vida». ${ }^{10}$ Desde París, le proporcionaba noticias del mundo literario, se ofrecía a enviarle novedades literarias [3,4] y le daba explicaciones de sus gestiones literarias en la casa Garnier [5, 6, 7]. Hasta retomó su idea juvenil de escribir un libro sobre Clarín que titularía La Obra de Leopoldo Alas y donde analizaría su importancia como crítico [6].

El resto de las cartas surgieron de estos intereses comunes y arrojan luz sobre los proyectos de Gómez Carrillo para hacer visible a Clarín fuera de España; en otras misivas le pide consejo o le agradece sus menciones en la prensa española, jalonando con reseñas la aparición de algunos de sus nuevos libros de ensayos y semblanzas.

En Los lunes de El Imparcial, el 11 de diciembre de 1893, comentó Clarín Sensaciones de arte. ${ }^{11}$ Agrupó en esta ocasión el crítico guatemalteco ensayos sobre

${ }^{9}$ Clarín, «Palique», Madrid Cómico, 20-II-1892. Citamos por sus Obras Completas, Oviedo, Ediciones Nóbel, 2002-2009, XII vols. Jean François Botrel e Yvan Lissorgues coords. En adelante abreviadas como OC. Texto citado, OC, VIII: 292.

${ }^{10}$ Enrique Gómez Carrillo, Treinta años de mi vida, III, Buenos Aires, 1921, pp. 30-36.

${ }^{11}$ Enrique Gómez Carrillo, Sensaciones de Arte, París, Biblioteca Azul, Ed. G. Richard, s. a. [1893]. Dedicado a Elías Zerolo. Existe una segunda edición en 1893 con «Liminar» de Salvador Rueda. 
artistas japoneses - Hokusai, Outamaro, Josai - con otros sobre Wilde, Verlaine o Zola. Además, un grupo de breves semblanzas sobre «los siete maestros», que es una reseña del libro de Julien Leclercq, Sept Sages et la jeunesse contemporaine: Renan, Taine, Flaubert, Baudelaire, Lisle, E. de Goncourt, Stendhal. No faltaban algunos otros artículos que habían llamado la atención como «El neo-misticismo» (dedicado a L. Alas) y «Tres sensaciones», recordando al excéntrico escritor cubano Julián del Casal desaparecido hacía unos meses, a quien también nombró en una de sus cartas [2].

Clarín destacaba en su reseña en primer lugar que Gómez Carrillo era uno de los elementos más valiosos de la colonia española en París por sus actividades editoriales. Recomendaba la lectura del libro «coquetón» y «muy elegante». Y después entraba ya en el terreno de las discrepancias:

El señor Carrillo es un modernista de los que no han dado en la flor de decir las cosas nuevas de modo que no las entendamos los viejos. Escribe el españolparisién con mucha claridad y precisión, con naturalidad simpática, y si no siempre es su lenguaje todo lo castizo que conviniera, he notado con placer que hay en este respecto visibles progresos en el último libro de Carrillo, si se compara con trabajos suyos anteriores. Es claro que escritores castellanos que apenas oyen hablar español, que hablan y escriben todo el día en francés, son los más expuestos al galicismo. ${ }^{12}$

Le preocupaba mucho a Clarín la contaminación del español por los galicismos, especialmente peligrosa para quienes vivían inmersos en ambientes franceses. Y hasta aprovechaba para hacer propaganda de otro de sus discípulos, Salvador Rueda, que había prologado la edición del libro que comentaba. Propaganda, pero contenida y no falta de reparos al propio Rueda, a quien censuraba que llamara a su prólogo «liminar». Era una forma de ejercer su control sobre el escritor malagueño, que se muestra lector de poesía francesa, pero huyendo de la pose decadente y estimaba la moderna crítica impresionista de Gómez Carrillo. ${ }^{13}$

Naturalmente se detuvo en el capítulo sobre el arte de la crítica, elogiando la lucidez de sus juicios y su imparcialidad, pero discrepando de sus teorías por extremadas y exclusivistas al proponer como modelo a Anatole France y la excesiva preponderancia que otorgaba a la crítica subjetiva basada en las sensaciones experimentadas durante la lectura. Difícilmente podía renunciar Clarín a la crítica analítica, basada en conceptos firmes y estables.

${ }^{12}$ Clarín, «Revista literaria», Los Lunes de El Imparcial, 11-XII-1893. En OC, VIII: 602.

13 Hemos estudiado la tutela intelectual de Clarín sobre Rueda en el estudio del epistolario que este dirigió al maestro: Vivir de la pluma: 25 cartas inéditas de Salvador Rueda y Rubén Dario a Leopoldo Alas, Clarín, en prensa. 
No podía dejar de aludir, en fin, al capítulo titulado «El neo-misticismo», que además estaba dedicado a él. Acorde con sus inquietudes de entonces, Clarín lo consideró el más notable del libro

\begin{abstract}
A mi ver, este capítulo es el más importante de la obra, el de más pensamiento, el que revela mejor lo mucho que alcanza el espíritu de Gómez Carrillo, que muestra aquí una prudencia, un tacto y una sinceridad que son admirables en muchacho de tan pocos años y solicitado, allí en París, por tantas exageraciones y extravagancias sugestivas, por tantos juegos malabares del espíritu. La materia es delicadísima y G. Carrillo, por si acaso, se cura en salud advirtiendo que lo que dice su poeta Marcelo de las nuevas idealidades místicas no debe ser considerado sino como una exposición mística impersonal. ${ }^{14}$
\end{abstract}

Lo felicitó por su noble intento de estudiar el neo-misticismo literario y la labor que hacía difundiendo esas hermosas iniciaciones del espíritu científico y artístico moderno. Aún sin entrar a detallar más, se aprecia la buena sintonía con el guatemalteco y cuánto sentía halagada su vanidad personal no solo porque le dedicara un capítulo como el citado sino porque en la entrevista con Zola publicada pusiera en sus labios que "Clarín es uno de los críticos que mejor me han estudiado en Europa». ${ }^{15}$ Gómez Carrillo había esperado con verdadera impaciencia la reseña de Clarín de este libro [5] y le agradeció una vez más sus observaciones cuando las recibió por carta [6].

El siguiente libro de Gómez Carrillo fue Literatura extranjera, publicado en $1895 .{ }^{16}$ Con prólogo de Jacinto Octavio Picón, quien aceptó escribirlo justamente por la intervención de Clarín según se trasluce de la carta [3]. En cierto modo marca en máximo punto de acercamiento a Clarín, a quien le dedica el libro. Picón aprovechó para elogiar a Clarín en su prólogo diciendo, además, que podía haberlo escrito él mucho mejor. Y señalaba que el libro llenaba un cierto vacío, informando a los lectores sobre escritores ignorados en el mundo hispánico en muchos casos. Y que lo hacía con una exposición amena de sus ideas y con cuidada taracea artística.

En Literatura extranjera, en efecto, hay básicamente dos partes bien diferenciadas, una referida a escritores del norte y la otra a franceses. Entre los primeros son ilustrativas las páginas dedicadas a Hauptmann o al cuentista alemán Heyse, al dramaturgo de moda Ibsen de quien comenta Peer Gynt, Nora de Casa de Muñecas y Romersholm. Y se deslizan otros nombres como los de Walt Whitman,

${ }^{14}$ Clarín, «Revista literaria», Los Lunes de El Imparcial, 11-XII-1893. En OC, VIII: 603.

${ }^{15}$ Gómez Carrillo, Sensaciones de arte, ob. cit., p. 126.

${ }^{16}$ Enrique Gómez Carrillo. Literatura extranjera. Estudios cosmopolitas, París, Garnier Frères, 1895. Dedicado «A Leopoldo Alas (París, 1894)» y con «Prólogo» de Jacinto Octavio Picón, fechado en Madrid, octubre de 1894. Clarín por tanto, debió proporcionarle la dirección de Picón que le solicitaba. 
Puckine o los dos evangelistas rusos Teodoro Wizewa y Richard Le Gallienne, con el primero de los cuales tuvo tratos por sus trabajos editoriales. De Francia transmitía información sobre todo acerca de poetas contemporáneos o de Villiers, amén de un buen número de notas sueltas e impresiones de lectura. Gómez Carrillo retomaba asuntos apenas abocetados en artículos anteriores, los refundía y ampliaba con su habilidad de publicista consciente de su labor mediadora para los lectores en lengua española y sacando también el mayor rendimiento material posible a sus escritos, basados en sus vivencias del mundo cultural parisiense con la aureola que ello confería a sus testimonios.

Vale la pena volver por unos momentos a la dedicatoria a Clarín. En ella, reconoce su admiración por el maestro y confiesa defectos que ya había advertido en Sensaciones de arte, porque «ni mi lengua ni mi estilo han experimentado transformación ninguna». ${ }^{17}$ Sin embargo, esperaba que notara los cambios sufridos en sus ideas:

\begin{abstract}
Ahora las "escuelas" me interesan menos que las obras, y los sentimientos me preocupan más que las palabras. Además, he llegado a comprender que no todo lo antiguo es malo, que no todo lo nuevo es hermoso, que no todo lo raro es admirable y que no todo lo sencillo es vulgar. Leyendo algo y reflexionando mucho, me he convencido de que, dentro de la filosofía literaria, es imposible tener principios invariables. ${ }^{18}$
\end{abstract}

Las lecciones clarinianas iban surtiendo el efecto apetecido por este. Debió leer con agrado su acercamiento a sus planteamientos:

Hoy, en vez de asegurar que "el buen crítico es el que hace novelas para uso de los espíritus sutiles y refinados", me contento con decir que "el buen crítico es el que escriba una página agradable después de leer un libro admirable". ${ }^{19}$

También esta vez, Gómez Carrillo avisó a Clarín del envío del libro, forzando así un acuse de recibo que no sabemos si se produjo $[8,10]$. Y como ya era habitual en él, cuando conoció la opinión de Clarín, se la agradeció educadamente [11].

El último momento de profunda convergencia se produjo en torno al nuevo libro misceláneo organizado por Gómez Carrillo bajo el título de Almas y cerebros, que acabaría publicándose en 1898 aunque le ocupó bastantes meses antes. ${ }^{20}$ Ahora fue

${ }^{17}$ Literatura extranjera, ob. cit., p. I.

${ }^{18}$ Ibid., pp. I-II.

${ }^{19}$ Ibid., p. II.

${ }^{20}$ Enrique Gómez Carrillo, Almas y cerebros. Historias sentimentales e intimidades parisienses. «Prólogo» de Leopoldo Alas. París, Garnier Frères, s. a. [1898]. Dedicada a Crisanto Medina. 
Clarín el prologuista, pero su situación personal había cambiado mucho respecto a los años anteriores, cerrándose cada vez más en sus planteamientos frente a los modernistas y demasiado condicionado por su salud que se iba deteriorando profundamente. Su prólogo tiene mucho de confesión de su estado, reconociendo que acaso no era ya la persona más indicada para escribirlo al tratarse de un libro «cosmopolita» y porque andaba desencantado de seguir a los jóvenes maestros y más vuelto a los estudios de la ciencia y de la filosofía. Reincidió en la valoración positiva de Gómez Carrillo como activo propagador de las literaturas internacionales aunque mostrando sus discrepancias.

Clarín tardó bastante tiempo en escribir este prólogo, lo que obligó a Gómez Carrillo a escribirle varias veces interesándose por el estado de su escrito $[12,13]$. Cuando el prólogo estuvo listo en septiembre se lo envió, publicándose también en Las Novedades de Nueva York. ${ }^{21}$ Era una forma de demostrar una vez más que seguía con interés el acaecer literario americano y también una oportunidad para explayarse exponiendo sus ideas acerca de la unidad que debiera existir entre las dos orillas del Atlántico gracias a la lengua española.

La disposición de Clarín en esas fechas era contradictoria: quería cumplir con su compromiso, pero a la vez pronunciarse con sinceridad sobre diferentes asuntos. Por ello no dejó de opinar con crudeza, tratando de diferenciar los verdaderos pensadores de los publicistas. Entre estos últimos consideraba a Max Nordau:

Max Nordau es uno de los personajes a quien el señor Gómez Carrillo se ha tomado el trabajo de visitar para estudiarlos de cerca, para oír de sus labios alguna confidencia que revelara, más o menos, el estado de alma del hombre notable a quien se quería observar.

Bueno, pues en mi humilde opinión, Max Nordau no merece que se le busque y sonsaque, ni las demás diligencias que Gómez Carrillo supone en la visita.

Max Nordau no es un sabio, no es un filósofo, no es un artista; es uno de tantos publicistas que entienden un poco de muchas cosas, y de todas ellas hablan y escriben, aprovechando para adquirir notoriedad, la armonía que existe entre su espíritu vulgar y de ideas superficiales y el espíritu de la gran masa de lectores adocenados. Max Nordau cultiva la especialidad de la brocha gorda y da escobazos, allí donde harían falta los más sutiles pinceles. ${ }^{22}$

${ }^{21}$ Clarín, «Un prólogo de Clarín. Literatura Hispana. Un libro de Gómez Carrillo», Las Novedades, 2-IX-1897. Aludirá a él posteriormente en OC, IX: 1113-1128.

${ }^{22}$ Clarín, «Prólogo». En OC, XI: 1128. No es el único ataque que le dirigió. Contestando a una carta -no localizada- que le había dirigido Gómez Carrillo diciendo que se había dignado en decir que Clarín tenía talento, este responde en las páginas de Madrid Cómico el 4 de julio de 1896: «Me importa un pito lo que diga Max Nordau. [...] Este señor quiere que el artista sea como él, un burgués de lo más chabacano. [...] Es un Schopenhauer de papel de estraza que resulta optimista a fuer de Bouvard y Pécuchet [...] Ese es Max Nordau, amigo Gómez Carrillo.» 
Y de aquí el consejo a Gómez Carrillo de que cuidara más la elección de las eminencias sobre las que escribía. No tenía dudas de que Ibsen era y seguiría siendo un gran escritor, pero tampoco que otros citados eran medianías que resistirían mal el paso del tiempo.

Preocupación central de Clarín durante aquellos años era cómo compaginar la actitud abierta frente a lo extranjero con la conservación de lo propio y genuino sin que se disolviera. Se trataba de asimilar lo foráneo sin aniquilar la tradición y por lo tanto la prudencia y tacto eran necesarios. Le parecía admirable el empeño de propagar ideas contemporáneas, pero siempre que el cosmopolitismo no hiciera olvidar lo propio, peligro que corrían quienes como Gómez Carrillo vivían desarraigados en la cosmopolita ciudad del Sena. Un último asunto tratado era la solidaridad hispánica que debiera existir entre América y España para evitar disolverse en lo extranjero, afianzando por el contrario el iberismo y haciéndolo valer.

El prólogo de Clarín tiene mucho confesión a tumba abierta de estas ideas que le inquietaban con lo cual la loa del libro quedaba tan en segundo plano que se sintió en la parte final obligado a justificar el porqué de su escritura desatada apelando a que Gómez Carrillo le conocía bien, tenía buen corazón y le comprendería:

Pero, ¿a dónde voy con todo esto? Perdóneme Gómez Carrillo, en gracia de la buena intención. Ya le decía al principio que era yo el hombre menos a propósito para poner prólogo a un libro en que se estudia el humor y hasta los caprichos de varios literatos y artistas, algunos eminentes de veras, otros, medianos, de veras también, y algunos, insignificantes.

[...] Yo no puedo, amigo Gómez Carrillo, decir aquí las mil y mil cosas que se me ocurren acerca de tan importante asunto. Si nos viéramos, si nos habláramos, si pudiésemos leer juntos, conversar días y días, casi me atrevo a creer que había de hacerle pensar a usted un poco en esta mi situación de ahora y no encontrarla irracional por completo.

De todas suertes, espero de su claro talento, y aún más de su buen corazón, que no vea en este prólogo, algo extraño sin duda, un sermón impenitente, ni una pose pedantesca, ni una salida de mal humor. Acaso, acaso, debí pulirlo un poco para darle más amable apariencia y disimular el mal sabor; pero con usted tales precauciones no son de importancia; [...] no es usted de los que intentan restaurarse con almíbar, y como de mi amistad y recia intención está seguro, no hay que poner ni quitar nada. ${ }^{23}$

«Algo extraño sin duda» era el prólogo, más una carta - como otras que le dirigió-, que una fría y distante faena de presentación. El tono confesional denota la cercanía afectuosa y la necesidad de encontrar interlocutores que Clarín sentía

${ }^{23}$ OC, XI: 1132-1134. 
por aquellas fechas en que veía que las fuerzas le iban abandonando y también que los gustos literarios estaban cambiando a un ritmo vertiginoso para él. Seguramente, con todo, tras varios años de relación y de haber peleado con ahínco para difundir la obra de Clarín en Francia y en América como lo había hecho, Gómez Carrillo esperaba un apoyo más decidido para su libro, pero aguantó bien el envite. Le escribió a Galdós:

Clarín me escribió un prólogo en el cual me atacaba fuertemente. Sí lo publiqué y se lo agradecí en el alma. ${ }^{24}$

No andaba errado Clarín al confiar en su buen corazón. Las dos últimas cartas que editamos confirman que la buena disposición de Gómez Carrillo con Clarín no cambió en los años siguientes. Trató de aclarar malentendidos como el suscitado por Las Heras cuando este quiso indisponerlo con José Martínez Ruiz [14]. Y también la última carta que incluimos testifica que contaba con el consejo de Clarín a la hora de traducir sus propias novelas al francés. Y para ello solicitó su opinión cuando Gabriel Montoya comenzó a difundirlo en las páginas de Gil Blas [15]. Ni cuando se convirtió en un escritor famoso y popular, olvidó Enrique Gómez Carrillo, que fue el para algunos híspido crítico ovetense quien le dio su primer espaldarazo notable en Europa. Las cartas que presentamos son un testimonio indiscutible y contienen datos de gran interés no solo para conocer una década de intercambios de opiniones entre ellos, sino sobre otros asuntos literarios, en particular cómo iba viviendo Clarín los cambios del panorama literario donde el modernismo, que él veía con tantas reticencias, avanzaba sin embargo, con paso firme e imparable.

\section{CARTAS}

Centro América

Guatemala, 30 de enero de 1890

Sr. Dn. Leopoldo Alas

Oviedo

Muy Señor mío: hace mucho tiempo que andaba yo buscando una coyuntura para escribir a usted una carta cualquiera; pero como la coyuntura no se presentaba

${ }^{24}$ Citado en nota, OC, XI: 1126. 
y yo no podía escribir a usted para decirle que le consideraba el primer satírico de España y aun de Europa, y uno de los primeros críticos, si no el primero también, he tenido que resignarme con mi suerte que me hacía permanecer callado y he estado durante algunos años leyendo todo lo que usted escribe en el Madrid Cómico y aprendiéndome de memoria pedazos de sus libros y de sus folletos literarios; citándolo como verdadera autoridad en todo lo que escribe, $y$, en fin, pensando en usted todos los días y a todas horas y hasta con deseos (no se ría usted, o, si quiere, ríase, pero créame por mi palabra y por mis barbas) con deseos, digo, de hacer un segundo viaje a España sólo por conocerle. Qué quiere usted; tal vez será locura, pero es la pura verdad.

Pero he aquí que cuando menos esperanzas tenía de ello, se me presenta, por mera casualidad, la deseada ocasión de escribir a usted sin exponerme a que se ría de mí. Un editor diligente y arriesgado va a comenzar a publicar, dentro de pocos días, una colección de folletos a imitación de los que está publicando en Madrid el Sr. Dn. Andrés R. Cobos, y habiéndome encargado a mí de escribir uno de ellos, con libertad para escoger la víctima, que diría Valbuena, ${ }^{25}$ le he escogido a usted, siempre que usted no disponga otra cosa, por cuya razón me tomo la libertad de pedirle su fotografía, una autógrafa cualquiera y algunos datos biográficos, que, espero en Dios y en su amabilidad, no me serán negados.

Suplicando a usted que perdone mis impertinencias en gracia de mi buena intención, y anticipándole las más expresivas gracias por el envío de los objetos pedidos y que para mí serán de grandísimo valor, aprovecho la oportunidad para decirle que soy su mejor amigo y su más apasionado admirador q. b. s. m.

$6^{\text {a }}$ Avenida Norte, $n^{\circ} 45$

Enrique Gómez Carrillo

$$
\mathrm{II}^{26}
$$

En Cuba acaba de morir Julián del Casal. ${ }^{27}$ Supongo que usted conocía algo suyo.

${ }^{25}$ Se trata del crítico Antonio de Valbuena, cuyas críticas satíricas seguía con atención. Sin embargo, cuando en 1898 lo conoció y pudo entrevistarlo en Madrid Cómico, la decepción resultó absoluta: «Intimidades madrileñas. Una visita a don Antonio de Valbuena», Madrid Cómico, 19-III-1898.

${ }^{26}$ Carta conservada fragmentariamente, que corresponde a 1893 por las alusiones a la muerte de Julián Casal.

${ }^{27}$ Julián del Casal (1863-1893) murió el 21 de octubre de 1893 a causa de un aneurisma provocado por una carcajada durante una reunión amistosa. 
Es una víctima de Huismann [sic]. ${ }^{28}$ Después de leer La Bas [sic] se puso a tomar opio y a celebrar misas negras... De eso murió.

Yo lo quise mucho.

Este es un documento humano.

¿Qué carta es esa que yo escribí a Bogotá? No; yo no he escrito nada...

10 de julio

Puesto que usted es tan amable, querido maestro, seguiré escribiéndole de vez en cuando para darle algunas noticias literarias de París y para pedirle algunos consejos.

Mil gracias por sus correcciones. ${ }^{29}$ Creo que el resto de mi libro está más correcto, pues desde hace seis meses sólo he leído autores castellanos —a Valera y a usted sobre todo; algo a Doña Emilia, algo a Picón y mucho a Armando Palacio, etc.

Permítame usted pedirle un nuevo servicio. Por circunstancias editoriales, necesito que mi libro tenga un prólogo de alguien que sea al mismo tiempo muy conocido y muy artista. En D. Juan Valera ni siquiera pienso porque sé que no hace ni una carta en menos de seis meses; en usted por otras razones de delicadezas; en Armando Palacio porque me lo figuro algo duro de carácter... El único que se me figura a propósito es Octavio Picón. ¿Podría usted darme una cartita de

Gómez Carrillo le dedicó «Tres sensaciones», recogidas en Sensaciones de Arte, París, Biblioteca Azul, Ed. G. Richard, s. a. [1893]. Dedicado a Elías Zerolo.

Sobre Casal: Francisco Morán, Julián del Casal o los pliegues del deseo, Madrid, Editorial Verbum, 2008. Y Julián del Casal, Poesía completa y prosa selecta, Madrid, Editorial Verbum, 2001. Edición de Álvaro Salvador.

${ }^{28}$ Joris Karl Huysmans, en efecto, fue su modelo vital y literario en gran parte. Casal le dedicó una cuidada semblanza en La Habana literaria el 15 de marzo de 1892: «Joris Karl Huysmans».

Su nombre real fue Charles Marie Georges Huysmans y fue un escritor francés cuyos escritos muestran una gran insatisfacción por la vida moderna y un hondo pesimismo. Tras su militancia naturalista, encontró su camino con la novela $A$ rebours ( $A$ contrapelo), cuyo protagonista Des Esseintes se convirtió en modelo de personaje decadente. Su giro espiritual de los años noventa dio lugar a obras extrañas como la citada La bas (1891) - Allá abajo-, mezclando demonología medieval con inquietudes de su tiempo.

${ }^{29}$ Debió enviarle parte de los ensayos para que le diera su opinión sobre ellos. Se aprecia que debió hacerle observaciones sobre su estilo, seguramente tratando de que corrigiera su galicismo. 
recomendación para él? Yo se la mandaría junto con las pruebas de mi libro. Creo que Picón es muy amable... Usted también lo es... y sin embargo, a usted no me atrevo a pedirle ese prólogo a pesar de que nada me gustaría tanto como ver el nombre de usted en la cubierta de un libro mío... Usted dirá... ${ }^{30}$

Lo de la aclimatación no es tan difícil como usted cree. ${ }^{31}$ Yo tengo ahora varios proyectos de los cuales no quiero hablar a usted por temor de que luego no se realicen. Creo que se realizarán, no obstante. ¿Quiere usted que siga mandándole los libros nuevos? La primera vez que le pregunté a usted si quería que lo hiciese, usted no me respondió.

Siempre amigo y admirador apasionado

Rue Le Verrier 17

Enrique G. Carrillo

\section{IV}

Jueves

Mil gracias por su carta, querido maestro; me ha llegado en un día de tristeza y ha sabido consolarme. Eso es raro en las cartas.

Creo que en el fondo ya tengo 40 años en cuestiones literarias. He tenido la desdicha de vivir en París, de ser personalmente casi francés, de hacerme querer de todos los literatos jóvenes y de ver los dessous del simbolismo. ${ }^{32}$

Eso me ha desconsolado mucho. Los que más gritan son los más fríos. Creo que sólo dos tienen verdadera fe (Morice y Moreas) y esos dos son los más sencillos: el primero imita a Spinoza, el $2^{\circ}$ a Virgilio. ${ }^{33}$

${ }^{30}$ Se refiere a Literatura extranjera. Estudios cosmopolitas, París, Garnier Frères, 1895. Dedicado «A Leopoldo Alas (París, 1894)» y «Prólogo» de Jacinto Octavio Picón, fechado en Madrid, octubre de 1894.

${ }^{31}$ Alude a su aclimatación a la vida parisiense donde realizaba trabajos editoriales y más adelante, cuando pudo, gestiones consulares.

${ }^{32}$ Dessous: adverbio francés, «debajo».

33 Charles Morice (1860-1919), escritor francés, poeta y ensayista. De sinuosa trayectoria, anduvo siempre muy atento al devenir de las artes plásticas escribiendo atinados ensayos.

Ya en Esquisses Gómez Carrillo le dedicó uno de sus breves retratos en la sección «Camafeos», recordando que se veía a sí mismo con perfil velazqueño, era un gran amante de todo lo español y buen amigo de Alejandro Sawa. 
Mallarmé fue para ellos una locura pasajera. ${ }^{34}$ Dentro de algunos meses ya sólo habrá simbolistas en América. Rubén Darío será el jefe... pero en el fondo Rubén no tiene nada de simbolista; sus obras son pastiches, a veces bien hechos, de Cátulo Méndez [sic]. ${ }^{35}$ Yo deseo acercarme a usted, con timidez naturalmente y siempre con el sombrero en la mano.

Mi libro Estudios cosmopolitas -que no será enteramente inútil para los españoles- llevará una dedicatoria a usted en la cual explicaré algunas de las razones de mi admiración por el autor de Mezclilla.

Mil gracias por la revista del Imparcial. ${ }^{36}$ Aún no la he visto pero ya se la he pedido a un amigo que lo recibe. Mil gracias, otra vez.

Le envío una nueva carta de Mme. Luizet. ¿Por qué no le escribe usted dándole la autorización que pide? Ya sabe usted, 138 rue de la Pompe. ${ }^{37}$

Para el Journal des Debats he hablado con un redactor: su Doña Berta le parece deliciosa; me ha dicho que le conviene perfectamente, que la publicará, pero que lo mismo puede ser mañana que dentro de un año porque el periódico está lleno de obras originales de personas influyentes; que esperara siempre una ocasión.

A Krentzberger no lo he visto desde hace más de 15 días; creo que no vendrá a París hasta dentro de dos semanas. ${ }^{38}$ Aquí tengo 20 cartas para él; Krentzberger está

Jean Moreas (1856-1910), cuyo nombre era Ioannis Papadiamantopoulos, fue un poeta griego de expresión francesa. Reclamó para sí mismo el título de simbolista desde 1886 y escribió numerosos ensayos sobre arte.

${ }^{34}$ Stephane Mallarmé (1842-1898) supuso por un lado la culminación del movimiento simbolista, pero también su superación abriendo el camino hacia las exploraciones poéticas vanguardistas. Se refería en todo caso a las evoluciones personales muy diferenciadas de los poetas citados.

${ }^{35}$ Catulle Mendès (1841-1909), poeta parnasiano francés, de origen portugués por parte paterna. Autor de una variada y versátil obra poética, además escribió también novelas, piezas teatrales y ensayos tan significativos como La légende du Parnasse contemporaine.

${ }^{36}$ Clarín, «Revista literaria», El Imparcial, 11-XII-1893. En OC, VIII: 578-584. Clarín elogia la valiosa labor que Gómez Carrillo está llevando a cabo en el mundo editorial francés y que ha sido encargado por la casa Garnier de inaugurar una biblioteca de autores españoles, cuyo primer tomo será una antología de prosistas españoles y americanos. Agradecía el esfuerzo de cuantos estaban editando libros en español en París, aunque insistía en que no presentaran como cosa exótica o rara a los escritores en español.

El resultado fue Cuentos escogidos de los mejores autores castellanos contemporáneos, Paris, Garnier Frères, 1894. Dedicado a Maurice Barrès. Coleccionados y con prefacio y noticias literarias de Enrique Gómez Carrillo. Abre la colección, iAdiós, cordera!, de Clarín.

${ }^{37}$ La traducción no se publicaría hasta el 31 de agosto de 1900 en la Nouvelle Revue Internationale.

${ }^{38}$ Krentzberger era uno de los impulsores en París de las ediciones españolas. Lo nombra Clarín en OC, VIII: 581. 
enamorado de una muchacha fea, por eso ha perdido mil periódicos que le pagaban; por ahora solo piensa en ella; y ella no merece que se piense en ella.

Perdone usted que le cuente estos potins sin importancia. ${ }^{39}$

En estos días no se ha publicado nada interesante.

Yo estoy encantado con Ibsen; ha sido una revelación para mí; estoy escribiendo un estudio sobre él. ${ }^{40}$

¿Qué más? En el París literario no sucede nada.

Hoy le mando un número de La Pluma en que hay un artículo del conde de Croix Mont sobre mí y mi retrato; lo citan a usted y exageran lo que usted dijo en el Madrid Cómico de mis pobres Esquisses. ${ }^{41}$ Usted perdonará la calumnia ¿no es cierto?

¿Qué piensa usted de Oscar Wilde? Yo no puedo juzgarlo bien; quiero demasiado al hombre y admiro mucho al escritor pero sé mal el inglés y Wizerva se mantiene burlándose de mí porque lo admiro. ${ }^{42}$ Una frase de usted me haría comprender algo de la verdad. ${ }^{43}$

Lo quiere tanto como lo admira

Enr. Gómez Carrillo

${ }^{39}$ Potins: del francés, «chismes».

${ }^{40}$ Enrique Ibsen (1828-1906), dramaturgo sueco que tuvo gran impacto en la literatura y en las ideas del cambio de siglo. Sobre su recepción en España y el papel mediador que tuvo Francia, véase, Jesús Rubio Jiménez, Ideología y teatro en España. 1890-1900, Zaragoza, Libros Pórtico, 1982.

Enrique Gómez Carrillo recogió este ensayo en Literatura extranjera: «Henrik Ibsen», comentando Peer Gynt, Casa de muñecas y Romersholm.

${ }^{41}$ Se refiere al «Palique» publicado en Madrid Cómico, el 20-II-1892, ya citado.

${ }^{42}$ Teodor de Wyzewa (Rusia, 1862-París, 1917), era periodista y musicólogo. Políglota y traductor, que sobrevivía de sus trabajos en el mundo editorial. En su tomo sobre Literatura extranjera (1895) le dedicó el ensayo, «Dos evangelistas rusos: Teodoro Wizewa y Richard Le Gallienne».

${ }^{43}$ Escribió sobre él ya en Esquisses, el retrato que abre el libro y dedicado a Alejandro Sawa, con quien había establecido una buena relación en París, frecuentando los mismos lugares y colaborando en la editorial Garnier. En otros libros le reservó mucho espacio: Sensaciones de arte (1893) o Almas y cerebros (1898), pero también en sus narraciones donde presentaba los ambientes artísticos parisienses.

Clarín respondió públicamente a su pregunta en su «Revista literaria», Los Lunes de El Imparcial, 11-XII-1893, donde reseña la segunda edición de Sensaciones de arte. Sobre el capítulo dedicado a Oscar Wilde indica que la semblanza es excesivamente apologética, pero que es escritor que «tiene talento, gracia, gusto, cierta originalidad formal por lo menos y esto explica el entusiasmo de la crítica subjetiva de Carrillo, que hace bien, a su edad (veinte años), en ser apasionado y muy amigo de sus aficiones.» (OC, VIII: 603) 
Querido Maestro,

Acabo de ver la revista literaria de usted. Muchas gracias; ${ }^{44}$ eso será útil para que lo vea Mr. Garnier.

Sin embargo, lo que yo esperaba con impaciencia era el artículo que sobre Sensaciones del Arte me tenía usted prometido pues además del bien inmenso que hará a mi vanidad, tendrá otro interés enteramente editorial o comercial. Mr. Richard es un editor que comienza: si con mi libro le va bien, seguirá; si no se detendrá. ${ }^{45}$ Y Mr. Richard es un editor que paga lo español como lo francés, es decir, muy bien, mejor que todos los de Madrid. En todo caso, le suplico a usted que si escribe sobre Sensaciones no hable de Mr. Richard, pues eso disgustaría a Garnier. ¡Qué difícil es estar bien con varios amos! Lo que importa es que mi libro se venda no por él mismo sino por los demás que pueden editarse en las mismas condiciones.

Me han hecho la promesa formal de publicar en Les Debats Doña Berta (no Cuervo ni Superchería aún) en cuanto acaben unas novelas que ya tienen sur le marbre.

Krentzberger va a llevar al suplemento literario del Fígaro, en cuanto pasen las fiestas rusas, un cuento de usted que estamos traduciendo. Su afmo.

Enrique Gómez Carrillo

\section{VI}

\section{Martes}

Querido maestro,

Hace algunos días tuve el gusto de recibir la carta en que usted me autoriza para hacer su libro en casa Garnier. ${ }^{46}$ De este mismo asunto quiero yo a mi vez decir algo a usted.

44 Debe tratarse del artículo, ya mencionado, Clarín, «Revista literaria», El Imparcial, 11-XII-1893, con elogios de la labor editorial de Garnier.

${ }^{45}$ Enrique Gómez Carrillo, Sensaciones de Arte, París, Biblioteca Azul, Ed. G. Richard, s. a. [1893].

${ }^{46} \mathrm{La}$ editorial Garnier, en efecto, creció en gran parte gracias a su visión de la importancia del mercado americano en lengua española. Disfrutaron del suculento monopolio de la edición escolar en Hispanoamérica donde se difundieron también sus diccionarios, devocionarios o misales. Además, célebres colecciones como la Biblioteca de 
La casa Garnier es un lugar que debe cultivarse por ser a la vez librería francesa y española. Eso nos puede servir un día para publicar traducida una obra de usted. (Yo estoy dispuesto a hacer que usted sea admirado en París y si no puedo hacerlo hoy lo haré mañana: las ideas fijas se consiguen). El que lo hace allí todo, o casi todo, es Zerolo, buena persona y gran admirador de usted. ${ }^{47}$ Él me ha dicho que le escriba en su nombre y para responderle deseo que usted me diga en una carta algo parecido a lo siguiente:

"Diga usted al Sr. Zerolo que le agradezco su proposición relativa a hacer en casa Garnier un florilegio de artículos míos y que desde luego autorizo a ustedes dos para que escojan en mis libros lo que les parezca, pues sé que el gusto literario de ustedes es muy... etc., etc., etc.,..."

Yo deseo hacer un libro que se intitule: La Obra de Leopoldo Alas, así como en Francia se hacen antologías de Hugo o Lamartine con títulos parecidos: en él deseo poner un artículo de cada una de las obras de usted diciendo el título de la obra y el año en que se publicó: también deseo que al principio del volumen vaya una noticia crítica y breve sobre usted, pero todo eso es cosa que usted dispondrá como le parezca. Le suplico que al responderme me envíe dos cartas: una diciéndome lo que al principio le suplico decir y otra dándome instrucciones sobre el modo de hacer el florilegio: la primera es para enseñársela a Zerolo y la segunda para saber lo que debo hacer. Después del libro de usted se publicarán otro de Pérez Galdós y otro de Castelar. Nada más. ${ }^{48}$

la mujer, Biblioteca Poética, Biblioteca selecta para los niños, Biblioteca selecta de la Juventud, etc.

En ella trabajaron como traductores muchos escritores españoles e hispanoamericanos: Antonio y Manuel Machado, Luis Ruiz Contreras, Alejandro Sawa, Enrique Gómez Carrillo, Luis Bonafoux, etc.

Véanse, además de los estudios de Jean-François Botrel sobre editoriales de entonces, Pura Fernández, «El monopolio del mercado internacional de impresos en castellano en el siglo XIX: Francia, España y "la ruta" de Hispanoamérica», Bulletin Hispanique, 100-1, janvier-juin 1998, pp. 165-190. Y «La editorial Garnier de París y la difusión del patrimonio bibliográfico en castellano en el siglo XIX», Miscelánea léxica en memoria de Conchita Serrano, Madrid, CSIC, 1999, pp. 603-612.

${ }^{47}$ Se trata del escritor y erudito canario Elías Zerolo Herrera (1848-1900) que dirigía las ediciones destinadas a Hispanoamérica. Gran estudioso de las variedades del español publicó obras como La lengua, la Academia y los académicos (Paris, Garnier, 1889). Dirigió obras colectivas como el Diccionario enciclopédico de la lengua castellana (Paris, Garnier, 1895, $5^{\text {a }}$ edición), o el Diccionario geográfico universal, de la misma editorial.

Véase, Javier Medina López, «Elías Zerolo (1848-1900) y la labor de la Real Academia Española», Revista de Filología Española, 87-2, 2007, pp. 351-371.

${ }^{48}$ Es uno de tantos proyectos que al parecer resultó fallido pues no figuran en su bibliografía estos libros. Véase, Juan Manuel González Martel, Enrique Gómez Carrillo (Guatemala, 1873-París, 1927). Obra literaria publicada en libro, segunda edición revisada 
Tengo de usted: Folletos, Mezclilla, Revistas y Pipá. ${ }^{49}$

Los demás es necesario enviármelos: por 300 pesetas el negocio es malo, pero no debe esto considerarse sino como principio de otros negocios.

Le agradezco a usted mucho lo que me dice de Sensaciones. ${ }^{50}$ Yo no tengo sino 20 años y la carta de usted equivale para mí a decirme: "continúe y podrá llegar a valer algo" ¡ojalá!

Créame siempre su amigo y admirador q. b. s. m.

En. Gómez Carrillo

Sigo esperando lo del Journal du Debats.

Si usted quiere, maestro, usted puede mandarme un artículo de los muchos que sobre usted se han escrito para ponerlo como prólogo a su libro; si no aquí puedo hacerlo yo [tachado, o Zerolo si usted gusta] para que todo parezca arreglado como se arreglan los florilegios en Francia: como homenaje para el autor y casi sin contar con él.

Krentzberger le agradece mucho su carta: está aprendiendo español y dentro de algunos meses será capaz de traducir obras literarias y de saborear los libros de usted; por lo pronto ya puede leer cartas.

Usted escribe perfectamente en francés ¿por qué no hace usted nada literario para alguna revista de París?

\section{VII}

retrato de usted, si usted nos lo permite.

Ya tiene Zerolo los libros de usted para el Florilegio, pero en casa Garnier todo va siempre muy despacio. ${ }^{51}$

Su admirador y amigo que b. s. m.

y aumentada, 2006. Edición digital incluida en la página de la Asociación Enrique Gómez Carrillo.

${ }^{49}$ No es muy preciso en sus datos, pero cabe entender que venía coleccionado tanto ediciones de las obras citadas como «revistas» o artículos sueltos de los que iba leyendo con pasión desde su adolescencia.

${ }^{50}$ Enrique Gómez Carrillo, Sensaciones de Arte, París, Biblioteca Azul, Ed. G. Richard, s. a. [1893].

${ }^{51}$ El carácter fragmentario de esta carta no permite precisar mucho más. Debe tratarse de alguno de los muchos proyectos barajados en la editorial, alentados siempre por Gómez Carrillo ante un siempre bien predispuesto Elías Zerolo. Se adivina la petición de alguna fotografía de Clarín con vistas a la ilustración o para la difusión de su obra. 
Jesús Rubio y Antonio Deaño Entre París y Oviedo: 15 cartas inéditas de Enrique Gómez Carrillo...

56, rue Monsieur.le-Prince, París

Enrique Gómez Carrillo

\section{VIII}

\section{Lunes París}

Mi muy querido maestro:

Mi primera ocupación al volver de un largo viaje es escribir a usted. He pasado cuatro meses por América y en todas partes he encontrado escritores que le admiran como uno de los más grandes críticos y novelistas modernos pero que le consideran como un enemigo jurado de América.

En Nueva York sobre todo he encontrado una gran colonia española que no vive intelectualmente sino de las crónicas que usted manda a las Novedades. ${ }^{52}$

No sé si ya usted recibió mi libro Literatura Extranjera. ${ }^{53}$ Usted me lo dirá.

Crea que le quiere y le admira como siempre, su afmo.

39 rue des Ecoles

Enrique Gómez Carrillo

\section{IX}

París. Mayo 12 de 1895

Mi muy querido maestro,

Acabo de recibir su carta, en la cual hay algo que me agrada mucho y algo que me desagrada profundamente. ${ }^{54}$

${ }^{52}$ Clarín se pronunció públicamente sobre el asunto en su «Revista literaria» de Las Novedades de 11-VII-1895. En OC, IX: 242-244. Se sentía muy honrado de que lo leyeran en América pero no comprendía que lo llamaran enemigo de América. Matizaba que nunca había escrito sobre asuntos de América que no tuvieran que ver con las letras y que lo hacía con entera libertad y sin eufemismos. Hablaba mal de algunos escritores malos de América por la misma razón que lo hacía sobre los españoles. No era antiamericanismo. Y hasta hacía una declaración de profunda fe en el iberismo de América en el futuro, asunto que retomó otras veces como en el «Prólogo» para Almas y cerebros (1898).

${ }^{53}$ Enrique Gómez Carrillo, Literatura extranjera. Estudios cosmopolitas, París, Garnier Frères, 1895. Dedicado «A Leopoldo Alas (París, 1894)». «Prólogo» de Jacinto Octavio Picón, fechado en Madrid, octubre de 1894. 
Entre lo que me agrada está lo referente a América, pues no hay escritor de por allá que no haga elogios de usted y no hay elogio que no termine diciendo: "lástima que Clarín sea el peor enemigo de América". Sus ideas a este respecto me parece, sin embargo, que son las más nobles y las más amplias. No hace diferencia ninguna entre los países que hablan español... Cuanto a los portugueses ya es otra cosa. A mí se me figura más compatriota nuestro un marsellés que un brasileño. En el fondo las grandes fronteras son las lenguas. Si usted escribe sobre este asunto en Las Novedades que es uno de los periódicos más leídos en América, ganará muchos amigos y hará cesar la única acusación que los americanos le hacen. ${ }^{55}$

Me desagrada que usted no haya recibido mi libro que, como ya sabe, está dedicado a usted. ${ }^{56}$ Hoy mismo se lo envío. También querría mandarle un ejemplar a D. José Yxart y si usted me da su dirección lo haré con mucho gusto. ${ }^{57}$ ¿A quiénes más puedo enviarles? En España hay poca gente de letras que se interesen por la crítica cosmopolita.

Lo que más me desagrada, como es natural, es lo que me dice del libro de ese homérida de Bonafoux que sabe recoger y publicar con tanto gusto las bromas de café. ${ }^{58}$ Ya Bonafoux me había dicho en varias ocasiones que pensaba escribir un

${ }^{54} \mathrm{Da}$ a entender que su correspondencia se había iniciado ya en las semanas o meses anteriores, quizás tras el palique que le dedicó en febrero en Madrid Cómico.

${ }^{55}$ Clarín había comenzado su colaboración con el periódico neoyorkino el 10 de marzo de 1892 con una sección titulada «Como gustéis. Revista de España, principalmente literaria». En OC, VIII: 306-313. Fue sobre todo entre 1894 y 1897 cuando envió la mayor parte de sus revistas literarias a este periódico. Véase, Adolfo Sotelo, «Clarín en Las Novedades de Nueva York (1894-1897): las letras americanas», en Perfiles de Clarín, Barcelona, Ariel, 2001, pp. 143-166.

La respuesta a Gómez Carrillo se puede leer también en las páginas de Las Novedades cuando el 11-VII-1895 escribía: «Yo hablo mal de algunos escritores malos de América, por la misma razón porque hablo mal de muchos escritores españoles: porque creo contribuir así, en lo poquísimo que puedo, al progreso de la vida intelectual de la tierra que considero patria, que es toda la peninsular y toda la americana hispano-portuguesa.»

${ }^{56}$ Se refiere a Literatura extranjera. Estudios cosmopolitas, París, Garnier Frères, 1895. Dedicado «A Leopoldo Alas (París, 1894)» y que lleva en efecto un «Prólogo» de Jacinto Octavio Picón, fechado en Madrid, octubre de 1894.

${ }^{57}$ Con buen criterio consideraba a José Yxart (1852-1895) otro de los críticos españoles con mejor visión moderna y cosmopolita de la literatura. Clarín tenía mucho trato con él y no le facilitó su dirección por lo que le insiste en otra carta. Yxart falleció ese mismo año.

${ }^{58}$ La aparición de Luis Bonafoux en sus cartas saca a escena una de las bestias negras de Clarín, que polemizó abundantemente con él desde 1887. Residía en París dedicado a labores de traductor y redactor para la casa Garnier, además de escribir en los periódicos. Ni siquiera fallecido Clarín dejó de escribir contra él. José María Martínez Cachero, «Luis Bonafoux, "Aramis", contra Clarín. (Historia de una enemistad literaria)», Revista de 
artículo diciendo que Zola no había nunca hablado de usted y en cierta ocasión en que supe que efectivamente estaba a punto de hacerlo en Madrid, pedí a Zola una tarjeta diciéndome que mi artículo era "juste et autentique" y se la mandé certificada. Él me ofreció entonces que no volvería a tratar de molestarle a usted por ese medio. Por lo demás ya sabe usted que mi artículo se publicó en francés en el Gil Blas cuando comenzó a aparecer Lourdes y en el New York Herald (en inglés) en el mismo número en que apareció el primer capítulo de la misma novela de Zola. ${ }^{59}$ Le agradecería mucho, sin embargo, que me indicase el título del libro ese, con nombre, de autor y de editor, para buscarlo.

Celebro el éxito de su drama y espero con impaciencia el ejemplar que de él me ofrece. $^{60}$

Le enviaré libros y revistas de París, aunque ahora comienza ya a ser menor la producción literaria por causa del verano. Aquí se publica mucho en otoño, algo menos en invierno y casi nada en estío.

No deje de escribirme. Créame su más sincero amigo y admirador

39 rue des Ecoles

Enrique Gómez Carrillo

\section{$\mathrm{X}$}

Consulado General

De la República del Salvador

Enrique Gómez Carrillo

49 Rue de Rivoli

París julio 15

Mi muy querido maestro

Literatura, 1953, pp. 99-112. Jena François Botrel, «Últimos ataques de Bonafoux a Clarín», Archivum, XVIII, pp. 177-188.

${ }^{59}$ Enrique Gómez Carrillo, «Emile Zola», en Gil Blas, 1894 (según González Martel, sin más precisiones). El asunto venía de más atrás. Clarín habló de ello en su «Revista literaria» de El Imparcial, 16-III-1893. Decía que había sido una de las mayores satisfacciones de su vida saber que le había dicho a un escritor español que «Clarín es uno de los críticos que mejor me han estudiado en Europa». Averiguó después que podía haber sido su editor quien le pusiera al tanto. Y defendía después su admiración por él y la necesidad de fomentar las relaciones internacionales del arte. (OC, VIII: 582)

${ }^{60}$ Debe referirse al debatido estreno de Teresa, que le habría mencionado Clarín en alguna de sus cartas. 
Hace más de dos meses que espero carta de usted. Estoy inquieto sobre la impresión que mi pobre Literatura Extranjera ha podido producir en usted. Temo, a causa de su silencio, que le haya disgustado.

Además deseo que usted me indique el título y el nombre del editor del libro en que se dice que Bonafoux dice que todo lo que yo digo de usted y Zola es falso.

El gobierno del Salvador me ha nombrado cónsul en París. Es un empleo que produce algo y que no da ninguna molestia. ${ }^{61}$

Acabo de recibir la tarjeta adjunta.

Soy siempre, su muy afmo.

49 rue de Rivoli

Enrique G. Carrillo

Le suplico me indique la dirección de D. José Ixart en Barcelona, para mandarle mi libro.

\section{XI}

París, septiembre 15 de 1895

Enrique G. Carrillo

49 Rue de Rivoli

Mi muy querido maestro:

Como ya le supongo a usted de vuelta, le dirijo esta a Oviedo.

Creo que el año próximo podré pasar el mes de agosto en el norte de España y, por supuesto, trataré de verle a usted en Gijón, que según parece es maravilloso como puerto de mar, o en Oviedo. Por ahora me helaré en París durante el invierno después de haberme asado durante el verano.

Mil gracias por su franqueza amistosa. Lo que usted me dice de la composición defectuosa de mi libro y de la mezcla algo snob de asuntos, países y nombres, me parece muy justo. ${ }^{62}$ Lo fatal es que uno no ve las cosas sino cuando ya están hechas. Yo me proponía estudiar las influencias del Norte en la literatura francesa; tomé

${ }^{61}$ De aquí la utilización de papel con nuevo membrete. El tiempo que Gómez Carrillo ocupó aquel puesto le permitió dedicarse más a la escritura de sus ensayos de divulgación de la cultura europea. Este alivio económico, con todo, no duró mucho tiempo y en el verano de 1897 fue relevado del cargo según le comunica a Clarín (carta de 6 de julio de 1897).

${ }^{62}$ Se refiere a Literatura extranjera. Estudios cosmopolitas, obra ya citada. 
muchas notas y luego me pareció más ¿cómo decir?... más epatant hablar de las que han influido que de las que han sufrido la influencia. En lo que me creí menos defectuoso aun después de ver impreso el libro es en lo que a lengua se refiere. Pero puesto que usted me dice lo contrario así debe de ser. A Dios gracias supongo que aún me queda tiempo para enmendarme. ${ }^{63}$

Mis próximos artículos serán más españoles por lo menos en la forma.

A propósito: desde que el Salvador me aseguró el pan de cada día nombrándome cónsul en París, he abandonado todas mis colaboraciones americanas. Antes escribía cuatro o cinco crónicas por semana para Venezuela, Guatemala, La Argentina, etc. Hoy mi único deseo es poder hacer una o dos veces al mes una Revista Parisiense para un gran periódico de América, no con objeto de cobrar sino con el fin de que los americanos no me olviden pues fatalmente yo tendré siempre necesidad de vivir de ellos. Si usted quisiera darme una carta de recomendación para el Director de las Novedades (que, después de la Ilustración Española es lo que más se lee en América) me haría un gran servicio. ${ }^{64}$ Yo mandaré la carta de usted junto con mi primera crónica y así estoy seguro de conseguir esa colaboración que tan útil me será.

Perdone usted que tanto le moleste y crea que la culpa no es mía sino de usted mismo que con su bondad infinita me autoriza a no escribirle nunca una carta sin pedirle al mismo tiempo un favor.

Soy siempre su más apasionado admirador y su más sincero amigo

Enrique Gómez Carrillo

Le agradecería en el alma que, si puede, me mande a vuelta de correo la recomendación para las Novedades, pues deseo comenzar pronto... si se puede.

Supongo que usted habrá escrito a la Señora Luizet y que ella le habrá ya mandado la traducción de Doña Berta. Yo no he vuelto a verla, ni ella ha vuelto a escribirme. ${ }^{65}$

E. G. C.

${ }^{63}$ Clarín, siempre preocupado por la excesiva influencia del francés en la manera de expresarse de los jóvenes escritores, debió hacerle recomendaciones en sus cartas para que siguiera ahondando en los recursos de la tradición literaria española.

${ }^{64}$ Ignoramos si Clarín le facilitó esta carta de recomendación.

${ }^{65}$ Debe corresponder a la traducción de la novela finalmente publicada por la Nouvelle Revue Internationale, $\mathrm{n}^{\mathrm{o}}$ 3, 31-VIII-1900. 


\section{XII}

París $1^{\circ}$ de mayo de 1897 - 49 rue de Rivoli

Mi muy querido maestro,

hace más de 15 días que espero con verdadera impaciencia una carta de usted para saber si ha recibido la mía y con ella las pruebas de mi libro.

En otras circunstancias no me inquietaría el silencio de usted que yo habría atribuido a sus ocupaciones; pero después del artículo de Fuente en Juan Rana, temo que usted esté resentido contra mí lo que no siendo justo sería, sin embargo, muy humano. ${ }^{66}$

Hoy me permito, pues, escribir a usted de nuevo para rogarle que me conteste sobre el asunto del prólogo. ${ }^{67}$

Usted tiene entera libertad para decir en ese prólogo lo que le parezca. Ya usted sabe que yo prefiero un consejo suyo a mil elogios de otros.

Esperando siempre una respuesta de usted, me repito su amigo de veras y admirador muy sincero

Rivoli 49

Enrique Gómez Carrillo

\section{XIII}

París, 6 de julio - 97

Mi muy querido maestro,

66 Durante la primavera de 1897 vivió Clarín una más de sus polémicas con diferentes escritores satíricos. La revista satírica Juan Rana comenzó a publicarse el día 18 de marzo de aquel año. En su redacción figuraban Fuente, Granés, Las Heras, Loma o Martínez Espada.

La polémica saltó a otras revistas como Gedeón donde al menos el 25-III- 1897 y el 1IV-1897, Francisco Navarro Ledesma ironizó sobre Clarín en sus artículos «Batir de Alas» el recuerdo irónico del verso becqueriano es evidente- y sus ideas sobre los poetas. Se refiere siempre a Clarinez, le acusa de tener manías persecutorias, de un afán desmedido por cobrar sus trabajos (la plutomanía) y en el segundo artículo hasta ridiculiza ;Adiós, cordera!

${ }^{67}$ Para Enrique Gómez Carrillo, Almas y cerebros. Historias sentimentales e intimidades parisienses. «Prólogo» de Leopoldo Alas. París, Garnier Frères, s. a. [1898]. Dedicado a Crisanto Medina. La novena historia recopilada, «Alma inquieta», va dedicada "A Clarín». Saldría con el retraso señalado según se ve en las cartas siguientes. 
hace mes y medio tuve el gusto de recibir, en respuesta a un telegrama, la carta en que bondadosamente accedía usted a mis deseos y me ofrecía enviarme el prólogo de Almas y cerebros una semana más tarde. ${ }^{68}$

Desde entonces no he vuelto a recibir carta ninguna de usted a pesar de un nuevo telegrama que me permití enviarle obligado por las reclamaciones diarias del editor, reclamaciones que duran aún, que redoblan, que me tienen ya enfermo.

Los editores han anunciado el libro para mediados de julio; lo han anunciado con prólogo de usted. Muchos libreros lo han pedido ya y en Buenos Aires y Méjico el editor tenía compromiso para entregar los ejemplares pedidos a fines de agosto. Naturalmente los tales editores me dicen que el causante de todo lo que pueda suceder de enojoso en la venta soy yo y hasta veo en ellos intenciones de no pagarme toda la suma prometida excusándose con el daño que les hago con mi atraso.

Esta es la principal razón que me obliga a suplicar a usted de nuevo que me envíe el prólogo.

Además hay otra razón, de menos importancia pero siempre muy grave para mí. El mes de julio es en París un mes de pagos: el 15 se pagan los alquileres, se pagan

68 Enrique Gómez Carrillo, Almas y cerebros. Historias sentimentales e intimidades parisienses. «Prólogo» de Leopoldo Alas. París, Garnier Frères, s. a. [1898].

El 2 de septiembre de 1897 Las Novedades de Nueva York incluyó «Un prólogo de Clarín. Literatura hispana. Un libro de Gómez Carrillo». El texto en OC, XI: 1.126-1.134.

El 30 de septiembre de 1897, La Ilustración Española y Americana ofreció «Paul Verlaine. Liturgias íntimas», en forma de carta dirigida a Enrique Gómez Carrillo. OC, IX: 1.113-1.119. Señala que aún no ha escrito el prólogo pedido para Almas y cerebros donde se dedican dos capítulos a Verlaine, del que le ha enviado su libro Liturgias íntimas, con variaciones sobre las fiestas religiosas. Le parece bien poca cosa. Le recomienda que no compare a Verlaine con Homero, Shakespeare o Hugo. Se le ha exaltado excesivamente convirtiéndolo en bandera de lo nuevo. Su mala y desarreglada vida ayudó a la construcción de su leyenda, pero no es un gran poeta en opinión de Clarín, le falta profundidad religiosa en sentido amplio.

Unos días después trató de demostrarlo con una segunda parte de su artículo: «Paul Verlaine. Liturgias íntimas (Conclusión)», La Ilustración Española y Americana, 8-X-1897. OC, IX: 1128-1136. Escrito dice, cuando ya Gómez Carrillo tiene el prólogo para su libro, por lo cual ya sabe sus tendencias. Clarín, que estaba preparando su curso sobre la nueva religiosidad para la serie de conferencias que debía dictar en la cátedra del Ateneo de Madrid, se embarca en una discusión de autores y tendencias compleja, que necesitaría largo análisis. Aplicado su razonamiento a Verlaine viene a decir que en él la presentación de lo religioso en su libro es impostado, de una aparente ingenuidad que se compagina mal con la perspicacia que mostró en muchas de sus opiniones.

Acerca de la visión de Clarín de la obra de Verlaine, John Kronik, "Clarín and Verlaine», Revue de Litttérature Comparée, XXXVIII, 1963, pp. 368-384. 
sastres, etc. y yo no cuento para satisfacer a mis acreedores sino con el dinero de mis Almas y cerebros. ${ }^{69}$

Hace tiempo que perdí el consulado del Salvador y desde entonces estoy reducido a las crónicas.

Por todos lados escribo y cada día escribo más: ahora hasta en Barcelona Cómica hago un artículo por semana. ${ }^{70}$

Espero pues, mi muy querido maestro, que usted no me hará ya esperar y que recibiré el prólogo.

Su admirador y amigo de veras

49 rue de Rivoli

Enrique Gómez Carrillo

\section{XIV}

DIARIO REPUBLICANO PROGRESISTA

EL PROGRESO

51-Montera-51

TELÉFONO No 43

Madrid jueves

\section{Queridísimo maestro}

Escribo a usted después de haber visto a Las Heras y autorizo a usted para que haga el uso que mejor le parezca, de la presente carta.

Las Heras es, en el fondo, un hombre honrado y caballeroso. Me ha dicho que "nunca en su vida ha visto a Martínez Ruiz y que jamás Martínez Ruiz ha escrito una palabra para el Juan Rana. Al escribir su truculento artículo del País, quiso, sencillamente parodiar las interwieus de nuestro amigo con Sellés y Benavente." ${ }^{11}$

${ }^{69}$ Aún así, Clarín se retrasó en la redacción de su prólogo hasta finales de septiembre y el libro no salió hasta el año siguiente.

${ }^{70}$ Barcelona Cómica, fue un semanario satírico ilustrado que se publicó entre 18891901. Equivalente barcelonés al Madrid Cómico madrileño, compartió colaboradores gráficos como Cilla o Mecachis. También literarios.

${ }^{71}$ Se trata de artículos que bajo el título de «Charivari» publicó Martínez Ruiz en La Campaña, periódico anarquista que dirigía en París Luis Bonafoux. Son entrevistas e impresiones sinceras con algunas personalidades del momento. Además de los citados comparecieron: Pardo Bazán, Vico, Unamuno, Ignacio Iglesias y Vicente Medina.

El número de 26 de febrero de 1898 trae la noticia de que Martínez Ruiz había sido desafiado por Dionisio de las Heras a causa de un artículo considerado injurioso. 
Yo conocí a Las Heras porque Martínez Ruiz nos encargó a Riquelme y a mí que le pidiésemos una satisfacción. De la campaña del Juan Rana contra usted solo conozco el artículo en que decían que Zola no me había hablado de usted. ${ }^{72}$ Las Heras me ha dicho ahora que fue él mismo quien lo hizo "porque me quería mal antes de conocerme y quería ponerme mal con usted."73

En Madrid me han recibido muy, muy bien. Hoy el Progreso y el Madrid me dieron un banquete en el cual brindamos todos por usted. ${ }^{74}$ En el número de mañana del Madrid Cómico hablo algo de usted, al protestar contra la condena de Zola; ${ }^{75}$ en

Sobre este periódico, véase, E. Inman Fox, «Dos periódicos anarquistas del 98», en Ideología y política en las letras de fin de siglo (1898), Madrid, Espasa Calpe, col. Austral, 1988, pp. 13-24.

${ }^{72}$ Se refiere a los ataques irónicos de Ricardo Fuente contra Clarín, ya mencionados. Respecto a las palabras elogiosas de Zola sobre Clarín, tal como hemos indicado en la introducción, las incluyó Gómez Carrillo en su artículo «Una visita a Emilio Zola», recogida en Sensaciones de arte (1893).

${ }^{73}$ Fue uno de los muchos encontronazos de José Martínez Ruiz con otros periodistas en aquellos años. En concreto lo sucedido entre febrero y marzo de 1898 cuando Las Heras publicó en El País un escrito calumnioso contra él, queriendo distanciarlo de Clarín. Martínez Ruiz reaccionó violentamente retándolo a un duelo. El 4 de marzo de escribió a Clarín sobre la falsedad de sus acusaciones y le anunció que Gómez Carrillo le enviaba también sus aclaraciones y que corresponden a la carta que editamos. Clarín que había pedido a Gómez Carrillo hiciera una averiguación sobre aquellas cuartillas supuestamente escritas por Martínez Ruiz contra él, cuando tuvo esta carta en su mano se refirió a ella públicamente en su «Palique» (Madrid Cómico, 15-III-1898): «Y el señor Gómez Carrillo escribe a Clarín y le autoriza para decirle en público, que el señor Las Heras le ha declarado que no hay tal artículo, así por consiguiente tales cuartillas, que Martínez Ruiz no le habló nunca, que todo ha sido una pura invención de la fecunda fantasía del señor Las Heras.» (OC, X: 129).

Véase la carta de Martínez Ruiz y algún otro detalle en Jesús Rubio Jiménez y Antonio Deaño Gamallo eds., El camino de las letras. Epistolarios inéditos de Rafael Altamira y José Martínez Ruiz (Azorín), con Leopoldo Alas (Clarín), Alicante, Publicaciones de la Universidad de Alicante, 2011, pp. 104-105.

${ }^{74}$ De este banquete en el restaurante La Bombilla, de Madrid, existen pruebas gráficas: una fotografía en la que se identifican entre otros Rubén Darío, Alejandro Sawa y ValleInclán. Incluida en la «Galería» de imágenes del escritor en la página de la Asociación Amigos de Enrique Gómez Carrillo.

${ }^{75}$ Enrique Gómez Carrillo, «Los hombres del día. Protesta», Madrid Cómico, 5-III-1898. Lo defiende a pesar de su condena en Sedan y protesta por su condena por defender a Dreyfus. Tiene alma de apóstol, dice, y es representado en una caricatura junto a un gendarme como un Ecce homo. Concluye citando a Clarín: «Si la juventud francesa te escarnece, la juventud de otro pueblo hermano te aclama, te sigue, te venera.» 
el número siguiente comenzaré mis intimidades madrileñas, iguales a mis visitas parisienses $;{ }^{76}$ principio por Valbuena $;{ }^{77}$ sigo con Dña. Emilia $;{ }^{78}$ todos mis intervievados me han hablado de usted, bien unos y otros mal; ¿me permite usted que repita todo lo que de usted me han dicho? Se lo pregunto a usted porque en el Madrid Cómico le quieren a usted tanto que son capaces de suprimir lo malo contra usted. (Yo hablaré siempre con simpatía de usted). ${ }^{79} \mathrm{Al}$ principio de la semana próxima me marcharé de nuevo a París; llevo excelentes impresiones de Madrid y trataré de volver pronto, quizás a quedarme.

Clarín escribió en aquellos meses artículos de total apoyo a Zola: «Palique. Abajo los judíos», Madrid Cómico, 31-I-1898 (OC, X: 83-86). «Palique», Madrid Cómico, 12-II-1898 (OC X: 96-99). «Palique», Madrid Cómico, 15-III-1898 (OC, X: 129-130).

${ }^{76}$ Estas entrevistas a escritores y artistas fueron en muchos casos la base de sus artículos donde mezclaba el retrato del personaje en su medio con sus declaraciones sobre su arte. Buena parte de su libro Almas y cerebros consiste en una recopilación de lo que llama «Intimidades parisienses».

${ }^{77}$ El 12-III-1898 anunciaron en Madrid Cómico que desde el número siguiente incluirían una nueva sección sobre «Intimidades madrileñas sobre literatos y artistas que ha visitado Enrique Gómez Carrillo». En este mismo número, Tomás Carretero incluyó «La novela de Carrillo» sobre Del amor, del dolor y del vicio, que consideró vigorosa de expresión, digna de ser leída y piropeó al autor como buena persona, con mucho talento y excelente camarada. Pero comentaba irónicamente que había hecho mal dándose una vuelta por Madrid porque le iban a surgir malos imitadores.

El día 19-III-1898, Enrique Gómez Carrillo, «Intimidades madrileñas. Una visita a don Antonio de Valbuena»: le resultó totalmente decepcionante en su encuentro en el hotel Rusia, dispuesto a ser diputado, desinteresado de la literatura, hallando defectos a Rubén Darío... Era alguien de otra época, que se aferraba a la tradición.

78 Emilia Pardo Bazán, «Intimidades madrileñas. Una visita a doña Emilia Pardo Bazán», Madrid Cómico, 23-IV-1898. Le recibió en un salón lujoso con amabilidad aristocrática; repasan asuntos: Las damas galantes, de Brantome, es uno de sus libros preferidos y sostiene que se puede contar todo pero con gracia. Valera sabe pintar esas escenas picarescas. Sostiene no haber vivido sino para el arte. Al preguntarle por Clarín se limita a decir. «No le conozco personalmente, es un escritor de talento...» Gómez Carrillo destaca que no quiere entrar en la intimidad, lo naturalista lo ve muy pasado y se siente ahora feliz.

${ }^{79}$ Lo que no podía imaginar Gómez Carrillo es que Clarín iba a ser nombrado director de Madrid Cómico a partir del 16 de abril de 1898. Ignoramos si la sección continuó después de estas dos entrevistas, pues al menos hasta finales de mayo no volvió a aparecer su firma. Acerca del paso de Clarín por la revista, al menos, Jean-François Botrel, "Clarín el Madrid Cómico. Historia de una colaboración (1883-1901)», en Clarín y "La Regenta" en su tiempo. Actas del Simposio Internacional, Oviedo, 1987, pp. 3-24. Margot Versteeg, «La pluma de hacer pesetas: las contribuciones de Leopoldo Alas al semanario Madrid Cómico», Bulletin of Hispanic Studies, 80-5, septiembre 2003, pp. 555-572. 
Mañana o pasado le enviaré mi novela Del Amor, del Dolor y del Vicio. ${ }^{80}$ Le ruego que escriba usted algo sobre ella; sé que no gustará a usted, pero no importa; aunque sea un palo, deseo unas líneas de usted.

Le quiere de veras

Enrique Gómez Carrillo

Escríbame usted al Progreso, al cuidado de nuestro querido Martínez Ruiz. ${ }^{81}$

\section{XV}

Faubourg Montmartre, 29

Querido maestro,

El poeta francés Gabriel Montoya acaba de traducir al francés mi novela Maravillas que aparece actualmente en el folletín de Gil Blas. ${ }^{82}$

Cuando esta publicación haya terminado, propónese mi amigo hacer en francés también una antología de cuentistas españoles entre los cuales desea que usted figure en primera línea. ¿Le autoriza usted a traducir uno de sus cuentos? ¿Cuál prefiere usted? ${ }^{83}$

Suyísimo siempre

${ }^{80}$ Enrique Gómez Carrillo, Del amor, del dolor y del vicio, París, Ed. La Campaña, 1898. Dedicada a Luis Bonafoux. La edición definitiva puede considerarse la publicada en París, Librería Americana, 1901, con prólogo de Rubén Darío. Recoge las novelas: El triunfo de Salomé, El crimen de Blanca, La guillotina y La suprema voluptuosidad. Esta última había sido editada suelta en Paris, s. a. [1897].

${ }^{81}$ Con José Martínez Ruiz había sintonizado bien. Durante estos meses la firma de este era habitual en Madrid Cómico sobre todo en una sección llamada «Gaceta de Madrid».

82 Enrique Gómez Carrillo, Les merveilles, Paris, ed. Gil Blas, 1899. Traducción de Gabriel Montoya. Antes, Enrique Gómez Carrillo, Maravillas. Novela funambulesca, Madrid, Casa Vda. de B. Rodríguez Serra, 1899. Con dedicatoria a Armando Palacio Valdés. También publicada otra edición en la librería madrileña de F. Fe, 1899.

Gabriel Montoya (1868-1914) fue un poeta y cantante francés que actuó en cabarets y en otros locales parisienses. Sus letras fueron utilizadas por muchos músicos. Es más desconocida esta faceta de traductor. En la sección «Día por día. Notas parisienses» que Gómez Carrillo publicó en La vida literaria mencionó en ocasiones a este personaje y trazó su semblanza situándolo en la taberna-cabaret Cuatro Artes. Véanse los números 5 (4-II1899), 9 (4-III-1899) y 24 (22-VI-1899). Una edición moderna en E. Gómez Carrillo, En plena bohemia, Gijón, Llibros del Pexe, 1999. Edición y prólogo de José Luis García Martín.

${ }^{83}$ Ignoramos si este proyecto se llevó a cabo. 
Jesús Rubio y Antonio Deaño Entre París y Oviedo: 15 cartas inéditas de Enrique Gómez Carrillo...

E. Gómez Carrillo

La Presse desea publicar también una novela mía traducida. Si usted conoce las dos tituladas Del amor del Dolor y del vicio y Bohemia sentimental, le ruego me diga cuál sería mejor traducir. ${ }^{84}$

En cuanto Les merveilles aparezcan en volumen, se las enviaré a usted. ${ }^{85}$ Hoy le envío un número del Gil Blas para que usted vea cómo traduce Montoya.

E. G. C.

${ }^{84}$ Le escribiera Clarín o no indicando su preferencia, lo cierto es que Gil Blas editó en 1899, Boheme sentimental (según González Martel). Ediciones en español: Enrique Gómez Carrillo, Bohemia sentimental, París, Ed. La Campaña, 1899. Y en Barcelona, casa editorial Ramón Sopena, 1899.

85 Enrique Gómez Carrillo, Les merveilles, Paris, ed. Gil Blas, 1899. Traducción de Gabriel Montoya. 